\title{
PENDIDIKAN KEDISIPLINAN DI PONDOK PESANTREN EL ALAMIA UNTUK MENANGGULANGI DEGRADASI MORAL
}

\author{
Ibnu Fiqhan Muslim ${ }^{1(*)}$, Sanudin Ranam ${ }^{2}$ \\ Universitas Indraprasta PGRI Jakarta, Indonesia \\ fiqhanmuslimibnu@gmail.com ${ }^{1}$, sanudinranam@gmail.com²
}

\begin{tabular}{ll}
\hline & \\
Received: & 28 Agustus 2020 \\
Revised: & 10 September 2020 \\
Accepted: & 04 Oktober 2020
\end{tabular}

\begin{abstract}
Moral menjadi kunci bangkitnya sebuah peradaban atau sebaliknya. Jika sebuah bangsa mampu membangun moral yang baik bagi masyarakatnya, maka akan terbentuk peradaban yang baik yang dapat memajukan bangsa tersebut. Dengan pedidikan kedisiplinan diharapkan mampu memperbaiki sikap manja yang terbentuk dalam diri siswa karena terbiasa dalam lingkungan keluarga. Kedisiplinan harus diajarkan mulai dari pemenuhan kepentingan diri sendiri (self service). Metode dalam penelitian ini menggunakan model analisis kausal efektual dengan menggunakan pendekatan rasional yang dirangkai berdasarkan hasil kajian pustaka (literature review). Metode yang digunakan peneliti menggunakan metode penelitian kualitatif, bukan data yang berasal dari tabel atau angka-angka hasil pengukuran yang dianalisis secara statistik, melainkan data penelitian kualitatif merupaka informasi kenyataan yang terjadi di. Sedangkan tehnik pengumpulan data pada penelitian ini adalah studi kasus menggunakan teknik wawancara, observasi, sekaligus studi dokumenter yang kemudian akan dianalisis menjadi suatu teori. Pendidikan kedisiplinan di Pesantren akan mampu merubah kebiasaan sebelumnya dengan kebiasaan baru yang lebih teratur dan positif. Selain itu, dipesantren juga anak di dekatkan dan dilatih untuk melaksankan ibadah sesuai dengan ajaran agama Islam yang kemudian akan terbentuklah suatu generasi yang memiliki akhlakul karimah.
\end{abstract}

Keywords: Pendidikan; Kedisiplinan; Degradasi Moral

(*) Corresponding Author: $\quad$ Muslim, fiqhanmuslimibnu@gmail.com, 0895345291840

How to Cite: Muslim, I. F. \& Ranam, S. (2020). Pendidikan Kedisiplinan Di Pondok Pesantren El Alamia Untuk Menanggulangi Degradasi Moral. Research and Development Journal of Education, 1(1), 102-109.

\section{INTRODUCTION}

Pendidikan memiliki peran penting untuk menjadikan individu lebih baik. Pendidikan diharapkan mampu memperbaiki karakter peserta didik. Guru sebagai subjek pendidik tidak sekedar mendidik dan memberikan materi akademik saja di sekolah, namun lebih dari itu. Guru diharapkan juga dapat menanamkan nilai-nilai positif pada siswa, dan kedisiplinan menjadi salah satu karakter yang harus dibangun.

Menangani persoalan tersebut, maka implementasi pendidikan karakter menjadi suatu keniscayaan. Pendidikan karakter bukanlah suatu topik yang baru dalam pendidikan. Pada kenyataannya, pendidikan karakter ternyata sudah seumur dengan pendidikan itu sendiri. Berdasarkan penelitian sejarah dari seluruh negara yang ada di dunia ini, pada dasarnya pendidikan memiliki dua tujuan, yaitu membimbing para pembelajar untuk menjadi cerdas dan memiliki perilaku berbudi (Lickona, 2013).

Moral menjadi kunci bangkitnya sebuah peradaban atau sebaliknya. Jika sebuah bangsa mampu membangun moral yang baik bagi masyarakatnya, maka akan terbentuk peradaban yang baik yang dapat memajukan bangsa tersebut. Karena kedisiplinan menjadi pondasi bagi bangsa. Dengan pedidikan kedisiplinan diharapkan mampu 
memperbaiki sikap manja yang terbentuk dalam diri siswa karena terbiasa dalam lingkungan keluarga. Kedisiplinan diajarkan mulai dari pemenuhan kepentingan diri sendiri.

Perilaku anak terbentuk dan dipengaruhi oleh berbagai macam faktor, antara lain faktor keluarga, lingkungan dan sekolah. Orang tua sebagai pendidik sebagaimana dicontohkan dalam Al Quran surat Luqman ayat 12-19 yang intinya mencakup bahwa Luqman sebagai orangtua mendidik anaknya dengan nasehat-nasehat mencakup pokopokok tuntunan agama, seperti akidahsyariah dan akhlak terhadap Allah, terhadap diri sendiri dan terhadap orang lain.

Menurut Hidayat (2019) Degradasi moral merupakan sebuah permasalahan besar yang terjadi pada saat ini, hal ini tentu saja banyak mengakibatkan penyimpanganpenyimpangan yang dilakukan oleh seseorang. Mengapa hal demikian bisa terjadi ? Jelas hal ini bisa terjadi karena buruknya moral para generasi kita dizaman sekarang ini. Beberapa penyebab penurunan moral tersebut ialah :

- Kurangnya pengawasan dari keluarga

- Teman pergaulan

- Kemajuan Iptek

- Mengikuti budaya luar

Degradasi moral pada remaja dapat kita lihat banyaknya berita penimpangan perilaku remaja dari perilaku bully, penggunaan obat terlarang, perbuatan asusila hingga tindak kriminal yang dilakukan para remaja. Diberitakan oleh salah satu media seperti okezone.com pada tahun 2020 bahwa masih banyak degradasi moral yang terjadi pada remaja, diantaranya yaitu ABG membawa Sajam di Cibubur, 4 remaja Pesta Miras, 16 remaja di Bantul hendak tawuran membawa sajam, remaja tawuran hingga tewas. Banyaknya kejadian ini meresahkan warga masyarakat dan orangtua yang memiliki anak remaja.

Karena di usia remaja biasanya anak mudah terpengaruh oleh lingkungan, terutama terpengaruh oleh teman sebayanya. Faktor ini yang kemudian menjadikan banyak orang tua yang mantap memasukan anaknya ke pesantren di usia ank-anak dan remaja. Dengan fondasi agama yang kuat, diharapkan anak tidak mudah terpengaruh dengan hal-hal negatif yang ada disekitarnya. Selain itu, di pesantren anak terikat dengan kebiasaan yang baik. Mulai dari bangun tidur hingga malam sebelum tidur. Tertib dengan segala tugas yang harus dikerjakan dan tidak bisa manja seperti ketika tinggal dirumah sendiri.

Begitu mengkhawatirkan jika banyak remaja yang mengalami degradasi moral, karena remaja adalah masa depan bangsa yang harus dipupuk atau dibina sebaik mungkin agar di masa depan mampu mengembangkan, mengabdi dan memimpin bangsa ini ke arah yang lebih baik dan lebih maju tentunya. Terlepas daripada itu, setiap orangtua menginginkan anak yang baik atau memiliki keturunan yang baik yang mampu menjaga nama baik keluarganya. Pesantren sebagai salah satu lembaga yang menyelenggarakan pendidikan formal dan nonformal menjadi pilihan tempat pembentukan karakter. Pesantren lembaga pendidikan yang memberikan fasilitas asrama, sehingga di anggap mampu membentuk karakter siswa dengan pendidikan kedisiplinan mulai dari disiplin terhadap diri sendiri.

Dengan demikian, banyak orang tua yang berpikiran bahwa pendidikan kedisiplinan dapat terapkan jika anak memiliki kepentingan tertentu. Sehingga mereka menyerahkan pendidikan kedisiplinan ke sekolah formal seperti pesantren. Karna peraturan yang dibuat disana harus dipatuhi. Sedangkan peraturan dirumah biasanya masih sedring dilanggar karena terdapat hubungan emosional antara anak dan orang tua. Hal tersebut yang kemudian mengakibatkan peraturan dirumah menjadi kendor, karena orang tua kurang tegas terhadap pelaksanaan dan pelanggaran peraturan yang terjadi. 


\section{LITERATURE REVIEW}

\section{Pendidikan Kedisiplinan}

Pendidikan keluarga merupakan hal yang sangat penting, karena di sinilah dibentuk dasar karakter seorang anak. Apakah anak tersebut akan dibentuk untuk memiliki karakter yang positif ataupun negatif, keluargalah yang menentukannya. Pendidikan karakter di sekolah ada yang disajikan secara nyata, baik berupa tambahan pelajaran khusus pendidikan karakter atau disajikan terpadu dalam bahan ajar, juga diwujudkan dalam kegiatan ekstra kurikuler (pengembangan diri) dan dimasukan sebagai muatan lokal.

Menurut Rachman (2004), pentingnya disiplin bagi para siswa sebagai berikut :

1. Memberikan dukungan bagi terciptanya perilaku yang tidak menyimpang.

2. Membantu siswa memahami dan menyesuaikan diri dengan tuntutan lingkunagn.

3. Cara menyelesaikan tuntutan yang ingin ditunjukkan peserta didiknya terhadap lingkungan.

4. Untuk mengatur keseimbangan keinginan individu satu dengan individu lainnya.

5. Menjauhkan siswa untuk melakukan hal-hal yang dilarang oleh sekolah.

6. Mendorong siswa untuk melakukan hal-hal yang baik dan benar.

7. Peserta didik belajar dan bermanfaat bagi dirinya dan lingkungannya.

8. Kebiasaan baik itu menyebabkan ketenangan jiwanya dan lingkungan.

\section{Degradasi Moral}

Degradasi dapat diartikan sebagai penurunan suatu kualitas. Dalam KBBI (Kamus Besar Bahasa Indonesia) (2008), degradasi dimaknai penurunan derajat, pangkat, kedudukan. Degradasi adalah perubahan yang mengarah kepada kerusakan di muka bumi. Degradasi di sini dimaksudkan penurunan kualitas maupun perusakan moral (demoralisasi).

Menurut Lilie (Budiningsih, 2008), kata moral berasal dari kata mores yang berarti tata cara dalam kehidupan atau adat istiadat. Menurur Dewey dalam (Budiningsih, 2008), mengatakan bahwa moral sebagai hal-hal yang berhubungan dengan nilai susila. Kohlberg (Budiningsih, 2008) seorang pakar pendidikan moral pernah mengatakan bahwa perkembangan moral seorang anak erat hubungannya dengan cara berpikir seorang anak memilki kemampuan untuk melihat, mengamati, memperkirakan, berpikir, menduga, mempertimbangkan, dan menilai, akan mempengaruhi perkembangan moral dalam diri anak. Semakin baik kemampuan berpikir anak, maka semakin besar kemungkinan anak memiliki perkembangan moral yang baik.

Anak dengan perkembangan moral yang baik diharapkan mampu memahami konsep moral yang baik dan kemudian berperilaku sesuai standar tersebut dengan konsisten. Namum demikian Kohlberg menambahkan bahwa pengertian hubungan yang erat antara kemampuan berpikir dan perkembangan seorang anak tidak menjamin bahwa anak yang cerdas akan memiliki perkembangan moral yang baik. Lebih jauh, dikatakan Kohlberg (Budiningsih, 2008)bahwa belum tentu anak atau seseorang yang cerdas akan menunjukkan perilaku moral yang baik, walau ia mengerti akan konsep moral yang sebenarnya.

Dalam KBBI (Kamus Besar Bahasa Indonesia) (2008), moral adalah ajaran baik buruk yang diterima umum mengenai perbuatan, sikap, kewajiban, akhlak, budi pekerti, susila. Kondisi mental yang membuat orang tetap berani, bersemangat, bergairah, berdisiplin, bersedia berkorban, menderita, menghadapi bahaya, isi hati atau keadaan perasaan sebagaimana terungkap dari perbuatan. 


\section{METHODS}

Pada penelitian sekarang ini, peneliti menggunakan metode penelitian kualitatif. Menurut Creswell (2008) dan Raco (2010), "metode penelitian kualitatif sebagai suatu pendekatan atau penelusuran untuk mengeksplorasi dan memahami gejala sentral". Sehingga data yang berasal dari penelitian kualitatif bukanlah berbentuk tabel atau angkaangka hasil pengukuran yang dianalisis secara statistik, melainkan data penelitian kualitatif merupakan informasi kenyataan yang terjadi di lapangan (Bungin, 2003 di Prastowo, 2010). Sedangkan tehnik pengumpulan data pada penelitian ini adalah studi kasus menggunakan teknik wawancara, observasi, sekaligus studi dokumenter yang kemudian akan dianalisis menjadi suatu teori. Dengan penelitian ini diharapkan akan memahami, menelaah, dan kemudian menafsirkan makna yang di dapat dari masalah dalam penelitian ini.

Model analisis yang digunakan dalam pembahasan topik utama dalam artikel ini menggunakan model analisis kausal efektual dengan menggunakan pendekatan rasional yang dirangkai berdasarkan hasil kajian pustaka (literature review). Model analisis yang dikembangkan mengikuti pola yang disarankan Ramdhani \& Ramdhani (2014) dan Ramdhani, Ramdhani, \& Amin (2014). Dalam persoalan kausalitas jarang dikaitkan dengan probabilitas. Hubungan kausal dijelaskan dari sisi efek penyebab dari pada sisi penyebab munculnya akibat. Begitu pula dengan penelitian ini yang merujuk pada responden yang dikenai perilaku dan tidak dikenai perilaku. Mereka yang di kenai perlakuan untuk belajar kedisiplinan belum tentu pula tidak mengalami degradasi moral. Karena faktor yang mempengaruhianya terlalu luas dengan jangka waktu yang cukup panjang. Akan tetapi, penilitian ini tetap dibuat untuk mengetahui adanya perubahan tingkah laku pada siswa minimal selama di dalam pesantren. Karena di dalam pesantren menerapkan kedisiplinan dari cara hidup dan cara bersosialisasi.

\section{RESULTS \& DISCUSSION}

\section{Result}

Moral yang seharusnya menjadi pengendali dalam bertingkah laku kian hari kian terkikis oleh kemajuan IPTEK abad 21. Dalam penerapan kedisiplinan di Pondok Pesantren El-Alamia diterapkan dalam keseharian di asrama. Mulai pada para santri bangun tidur sampai dengan tidur kembali. Setiap hari mereka memiliki agenda kegiatan yang harus dilaksanakan sesuai dengan tata tertib pondok pesantren.seperti bangun pada pukul 03.00 pagi untuk kemudian melaksanakan qiyaamul layl dan berlanjut melaksanakan solat subuh secara berjamaah di masjid,pelaksanaan tadarus dan menghapal kosakata bahasa arab dan inggris karena di pesantren el alamia mewajibkan para santrinya untuk berkomunikasi dengan dua bahasa tersebut,para santri juga di wajibkan untuk selalu melaksanakan solat wajib secara berjamaah sehingga ketika masuk waktu solat fardu (wajib) mereka harus meninggalkan semua aktifitas apapun.

Kaitan dalam kegiatan belajar mengajar,para santri juga di wajibkan untuk datang tepat waktu dikelas dan menggunakan atribut wajib seperti peci dengan memakai kemeja dan celana panjang,bagi santriwati wajib berhijab dan menggunakan pakaian yang menutup aurat secara sempurna dan wajib menggunakan kaos kaki.untuk kegiatan sosial santri laki laki dilarang keras berinteraksi dengan santri perempuan tanpa sepengetahuan pimpinan dan pengurus pondok, hal ini di maksudkan agar terhindarnya para santri dari pergaulan yang tidak di inginkan.pesantren el alamia juga menerapkan hukuman yang bersifat mendidik bagi santri yang melakukan pelanggaran terhadap aturan dan tata tertib pondok,hukuman di sesuaikan dengan berat atau ringannya pelanggaran yang 
dilakukan.untuk aktifitas mandi,makan dan tidur para santri,pondok juga memberikan waktu waktu tertentu,terkait masalah kebersihan pondok,para santri diwajibkan membersihkan lemari pakaian dan peralatan nya masing masing dan melaksanakan piket kamar asrama untuk di bersihkan setiap hari nya (piket kamar di atur oleh kepala asrama),dan secara umum para santri diwajibkan melakukan kerja bakti setiap hari jumat di lingkungan pondok pesantren.

Dengan pendidikan karakter, peradaban mulia suatu bangsa dapat tercapai karena seperti yang dikatakan oleh Aqib (2012) pendidikan karakter lebih menekankan kepada pembentukan potensi dasar seperti:

1. Membangun iman, dengan ini akan lahir pribadi-pribadi yang dapat mengendalikan diri dan meyakini bahwa apa yang mereka lakukan kelak akan dimintai pertanggungjawaban oleh Allah Swt. Dari pancaran keimanan ini muncul pribadipribadi yang jujur, bertanggung jawab, amanah, dan berakhlaq mulia.

2. Memupuk akhlak, dengan memupuk akhlak yang baik akan membuahkan insan-insan yang berbudi mulia

3. Pendidikan berbasis minat dan bakat, menempatkan seseorang sesuai dengan keahliannya dalam suatu pekerjaan.

4. Pendidikan berbasis doa dan riyadoh (berlatih), Rasulullah mengajarkan bahwa doa merupakan sesuatu yang penting bagi setiap insan.dengan mengawali dan mengakhiri semua kegiatan dengan berdoa,tentunya akan melatih diri agar senantiasa menjalankan semua hal dengan di dasari beribadah kepada allah,sehingga akan terbentuk suatu sikap berserah diri (tawakkal) kepada allah.

Menurut Diknas mulai tahun ajaran 2011, seluruh pendidikan di Indonesia harus menyisipkan nilai-nilai pendidikan berkarakter kepada para siswa dalam proses pendidikannya. Ada 18 nilai-nilai pendidikan karakter, yaitu:

1) Religius : Sikap dan perilaku yang patuh dalam melaksanakan ajaran agama yang dianutnya, toleran terhadap pelaksanaan ibadah agama lain, dan hidup rukun dengan pemeluk agama lain.

2) Jujur : Perilaku yang didasarkan pada upaya menjadikan dirinya sebagai orang yang selalu dapat dipercaya dalam perkataan, tindakan, dan pekerjaan.

3) Toleransi : Sikap dan tindakan yang menghargai perbedaan agama, suku, etnis, pendapat, sikap, dan tindakan orang lain yang berbeda dari dirinya.

4) Disiplin : Tindakan yang menunjukkan perilaku tertib dan patuh pada berbagai ketentuan dan peraturan.

5) Kerja Keras : Tindakan yang menunjukkan perilaku tertib dan patuh pada berbagai ketentuan dan peraturan.

6) Kreatif : Berpikir dan melakukan sesuatu untuk menghasilkan cara atau hasil baru dari sesuatu yang telah dimiliki.

7) Mandiri : Sikap dan perilaku yang tidak mudah tergantung pada orang lain dalam menyelesaikan tugastugas.

8) Demokratis : Cara berfikir, bersikap, dan bertindak yang menilai sama hak dan kewajiban dirinya dan orang lain.

9) Rasa ingin tahu : Sikap dan tindakan yang selalu berupaya untuk mengetahui lebih mendalam dan meluas dari sesuatu yang dipelajarinya, dilihat, dan didengar.

10) Semangat kebangsaan : Cara berpikir, bertindak, dan berwawasan yang menempatkan kepentingan bangsa dan negara di atas kepentingan diri dan kelompoknya.

11) Cinta Tanah air : Cara berpikir, bertindak, dan berwawasan yang menempatkan kepentingan bangsa dan negara di atas kepentingan diri dan kelompoknya. 
12) Menghargai Prestasi : Sikap dan tindakan yang mendorong dirinya untuk menghasilkan sesuatu yang berguna bagi masyarakat, dan mengakui, serta menghormati keberhasilan orang lain.

13) Bersahabat/Komunikatif : Sikap dan tindakan yang mendorong dirinya untuk menghasilkan sesuatu yang berguna bagi masyarakat, dan mengakui, serta menghormati keberhasilan orang lain.

14) Cinta Damai : Sikap dan tindakan yang mendorong dirinya untuk menghasilkan sesuatu yang berguna : bagi masyarakat, dan mengakui, serta menghormati keberhasilan orang lain.

15) Gemar Membaca : Kebiasaan menyediakan waktu untuk membaca berbagai bacaan yang memberikan : kebajikan bagi dirinya.

16) Peduli Lingkungan : Sikap dan tindakan yang selalu berupaya mencegah kerusakan pada lingkungan alam di sekitarnya, dan mengembangkan upaya-upaya untuk memperbaiki kerusakan alam yang sudah terjadi.

17) Peduli Sosial : Sikap dan tindakan yang selalu ingin memberi bantuan pada orang lain dan masyarakat yang membutuhkan.

18) Tanggung Jawab : Sikap dan perilaku seseorang untuk melaksanakan tugas dan kewajibannya, yang seharusnya dia lakukan, terhadap diri sendiri, masyarakat, lingkungan (alam, sosial dan budaya), negara dan Tuhan Yang Maha Esa.

Jika seorang siswa berkarakter maka akan menjadi pribadi yang berkualitas, cerdas secara intelektual dan juga bermoral. Faktor terpenting dalam pendidikan karakter adalah orang tua, karena penanaman nilai-nilai agama, dan dasar-dasar kehidupan dipelajari untuk pertama kalinya di lingkungan keluarga. Selain dari pada itu, anak usia SD lebih banyak menghabiskan waktunya dengan orang tua, tahap meniru nya pun masih sangat tinggi. Namun walau bagaimanapun faktor eksternal tidak bisa dilupakan, lingkungan sekolah, lingkungan masyarakat dalam hal ini lingkungan bermainnya merupakan hal yang berpengaruh juga dalam pembentukan karakter anak.

Pendidikan karakter merupakan aspek yang sangat penting karena menentukan ranah yang menentukan keberlangsungan suatu bangsa di benua manapun termasuk Indonesia, tapi pada praktiknya menerapkan pendidikan karakter tidak semudah membalikan telapak tangan. Maka harus ada sinergitas antara orang tua, guru, dan masyarakat demi terciptanya masyarakat madani barkarakter.

Begitu juga pendidikan kedisiplinan di Pesantren El Alamia, walaupun terbatas karena tidak dimulai dari kecil. Tapi diharapkan akan mampu merubah pola asuh dari keluarga yang biasanya memanjakan anak dengan fasilitas yang ada dirumah. Selain kediplinan, dipesantren juga anak di dekatkan dan dilatih untuk melaksankan ibadah sesuai dengan ajaran agama Islam. Dengan kebiasan disiplin tersebut diharapkan akan membentuk moral dan perilaku yang baik bagi para santri. Sehingga, terbentuklah suatu generasi yang memiliki akhlakul karimah.

\section{Discussion}

Karakter tersusun dari tiga bagian yang saling berhubungan, yakni: moral knowing (pengetahuan moral), moral feeling (perasaan moral), dan moral behavior (perilaku moral). Karakter yang baik terdiri dari pengetahuan tentang kebaikan (knowing the good), keinginan terhadap kebaikan (desiring the good), dan berbuat kebaikan (doing the good). Dalam hal ini, diperlukan pembiasaan dalam pemikiran (habits of the mind), dan pembiasaan dalam hati/perasaan (habits of the heart), dan pembiasaan dalam tindakan (habit of the action) (Zubaedi, 2011: 13).

Untuk menghasilkan moral yang baik, seorang remaja harus mengetahui, merasakan dan melaksanakan segala sesuatu yang baik. Pembiasaan ini harus dilakukan 
secara terus menerus dalam jangka waktu yang relatif lama agar terbentuk karakter yang baik pada remaja. Karena jika telah memiliki karakter perilaku yang baik, kedepannya remaja tersebut diharapkan tidak akan salah dalam melangkah. Sehingga menjadi manusia dewasa yang memiliki arah dan tujuan yang jelas dalam hidupnya.

Orangtua dengan perasaan yang terlalu sayang terhadap anak, kadang kala tidak mampu mengajarkan disiplin dan bertindak tegas terhadap anak yang lalai terhadap kewajibannya.. Sebagian orangtua menyerahkan pendidikan moral untuk remaja dengan memasukkannya di Pondok Pesantren. Hal ini terbukti banyak lulusan pondok pesantren yang memiliki jiwa mandiri dan mampu memahami baik dan buruk secara mendalam. Karena di Pondok Pesantren para santri wajib mengerjakan tugasnya dan memiliki jadwal atau rutinitas positif setiap harinya. Para santri mendapatkan hadiah dan hukuman atas apa yang menjadi tindaknnya. Berbeda jika remaja yang tumbuh dirumah, mereka tidak benar-benar mengerjakan kewajibannya karena biasanya orangtua tidak memberikan hukuman atas kelalian anaknya.

Apalagi di jaman teknologi seperti sekarang, anak remaja telah memiliki smart phone untuk keperluan sekolah dan bersosial media. Tetapi kebanyakn dari mereka yang menyalahgunakan fasilitas ini. Para remaja hanya berlama-lama dengan smart phone mereka, sedangkan tugas sekolah maupun tugas dirumah tidak diselsaikan. Ini menjadi tantangan besar bagi orang tua, karena harus mampu dengan bijak memberikan ruang untuk anak agar tetap seimbang menggunakan gaadget dan menyelesaikan tugasnya. Bukan harus 24 Jam di awasi, tetapi bagaimana caranya agar remaja tetap mampu dikendalikan agar memiliki karakter dan kebiasanaan yang baik. Selain mengakibatkan remaja menjadi lalai terhadap kewajibannya, gadget juga memiliki efek negatif lainnya, seperti mudah tantrum dan efek radiasi terhadap mata dan otak.

\section{CONCLUSION}

Jika dengan tata tertib yang runtut membuat anak menjadi disiplin, sopan santun dan taat terhadap peraturan. Hal tersebut terbukti dengan banyaknya lembaga pendidikan yang berfokus untuk memperketat peraturan dan disiplin. Dan biasaanya semakin baik prestasi sebuah sekolah, semakin detail peraturan yang dobuat sekolah. Karena anak yang cerdas tidak hanya membutuhkan pengetahuan yang banyak dan kemudian menjadi pandai. Anak yang pandai wajib memiliki perilaku atau akhlak yang baik. Sehinggan ilmu yang dimilikinya kelak, dapat dimanfaatkan utnuk kebaikan diri sendiri dan kebaikan orang banyak.

\section{REFERENCES}

Budiningsih, C. Asri. 2008. Pembelajaran Moral. Jakarta: PT Rineka Cipta.

Hidayat, Riki Hendri. (2019). Degradasi Moral Generasi Muda. https://www.kompasiana.com/rikihendrihidayat/5cdc4e9e95760e0df52cd3f4/degra dasi-moral-generasi-muda?page=all (diakses tanggal 25 september 2020).

Jahroh, Windi Siti \& Sutarna, Nana. Pendidikan Karakter Sebagai Upaya Mengatasi Degradasi Moral. Prosiding Seminar Nasional Inovasi Pendidikan Inovasi.Pembelajaran Berbasis Karakter Dalam Menghadapi Masyarakat Ekonomi Asean.

Lickona, Thomas. (2013). Education for Character: Mendidik untuk Membentuk Karakter. Jakarta: Bumi Aksara. 
Lickona, Thomas. (2012). Character Matters: Persoalan Karakter, Bagaimana Membantu Anak Mengembangkan Penilaian Yang Baik, Integritas Dan Kebijakan Penting Lainnya (Terjemahan). Jakarta: Bumi Aksara.

Maragustam. (2016). Filsafat Pendidikan Islam Menuju Pembentukan Karakter Menghadapi Arus Global. Yogyakarta : Kurnia Kalam Semesta.

Muchlas, Samani, dan Haryanto.(2011). Pendidikan Karakter. Jakarta : PT Remaja Rosdakarya.

Muthohar, Sofa. (2013).Antisipasi Degradasi Moral di Era Global. Jurnal Pendidikan Islam. IAIN Walisongo Semarang

Nurihsan, A. Juntika dan H. Mubiar A. (2013). Dinamika Perkembangan Anak \& Remaja, Tinjauan Psikologi, Pendidikan, dan Bimbinga. Bandung: Refika Aditama.

Okezone.com. (2020). Kenakalan Remaja. https://www.okezone.com/tag/kenakalan remaja (diakses tanggal 25 september 2020)

Ramdhani, M. A., \& Ramdhani, A. (2014). Verification of Research Logical Framework Based on Literature Review. International Journal of Basic and Applied Science, 03 (02), 1-9.

Zubaedi. (2011). Desain Pendidikan Karakter: Konsepsi dan Aplikasinya dalam Lembaga Pendidikan. Jakarta: Kencana. 